\title{
Cell Sheet Tissue Engineering for Heart Failure
}

\author{
Hidekazu Sekine, Tatsuya Shimizu, and Teruo Okano
}

\begin{abstract}
In recent years, regenerative medicine using cells for treating tissue defects has been in the spotlight as a new treatment for severe heart failure. Direct injection of bone marrow-derived cells and isolated skeletal myoblasts has already been used clinically as a method to improve cardiac function by regenerating cardiac muscle cells and blood vessels. The research on reconstructing functional three-dimensional (3D) cardiac grafts using tissue engineering methods has also now been addressed as a treatment for the next generation. Our laboratory has proposed an original tissue engineering technology called "cell sheet engineering" that stacks cell sheets to reconstruct functional 3D tissues. Transplantation of cell sheets has already shown it can cure damaged hearts, and it seems clear that the field of cell sheet tissue engineering can offer realistic treatment for patients with severe cardiac disorders.
\end{abstract}

\section{Keywords}

Cardiac tissue engineering $\bullet$ Cell sheet $\bullet$ Regenerative medicine

\subsection{Introduction}

Heart transplantation is the last hope for treatment of patients with severe heart failure due to ischemia-related disease and dilated cardiomyopathy. However, the lack of donor organs for transplantation continues to be a serious problem around the world. Although there have been many developments in artificial heart systems such as mechanical temporary assist devices or left ventricular assist devices (LVADs), there are also problems in conjunction with thromboembolism, infection, and finite

\footnotetext{
H. Sekine • T. Shimizu • T. Okano $(\bowtie)$

Institute of Advanced Biomedical Engineering and Science, Tokyo Women's Medical University, 8-1 Kawada-cho, Shinjuku-ku, 162-8666 Tokyo, Japan

e-mail: tokano@twmu.ac.jp
}

T. Nakanishi et al. (eds.), Etiology and Morphogenesis of Congenital Heart Disease, DOI 10.1007/978-4-431-54628-3_3 
durability. Given these challenges with current technologies, regenerative therapies are being investigated as an alternative approach and present new possibilities for the repair of a damaged heart. Recently, the direct injection of either autologous skeletal myoblasts or bone marrow-derived cells has been examined in clinical studies as an alternative cell source to cardiac muscle cells [1-3]. The direct injection of the dissociated cells has shown to be slightly effective, but it is often difficult to control the form, dimensions, or the position of implanted cells. In an attempt to solve these problems, research on advanced therapies using functional tissue produced by engineered cardiac grafts has started. Over the past decade, several studies have proved that bioengineered cardiac tissues could improve cardiac function in animal models of impaired heart [4]. In this review, we discuss the progress of research on myocardial regeneration with a focus on our own original approach using cell sheet engineering.

\subsection{Cell Sheet Engineering}

We have developed our own "cell sheet engineering" method using temperatureresponsive culture dishes created by the covalent grafting of a temperature-responsive polymer, poly( $N$-isopropylacrylamide) (PIPAAm), to normal cell culture dishes [5]. Under normal culture conditions at $37^{\circ} \mathrm{C}$, the dish surface is relatively hydrophobic, and cells can attach, spread, and proliferate similar to commercially available tissue culture surfaces. However, when the temperature is reduced to below the polymer's lower critical solution temperature of $32{ }^{\circ} \mathrm{C}$, the polymer surface becomes hydrophilic and swells, forming a hydration layer between the dish surface and the cultured cells. This allows the cells to detach as a single sheet without the need of enzymatic treatments such as trypsinization. Since the use of proteolysis measures is unnecessary, critical cell surface proteins and cell-to-cell junction proteins remain intact, so that the cells can be harvested noninvasively as an intact sheet while retaining their extracellular matrix (ECM) (Fig. 3.1). Consequently, we can recreate $3 \mathrm{D}$ structures such as cardiac tissue by repeated layering of individual cell sheets [6].

\subsection{Cardiac Tissue Reconstruction}

Harvested cell sheets consist of only confluently cultured cells with their biological ECM on the basal side of the cell sheets, which acts as an adhesive agent for promoting an intimate attachment between each layered cardiac cell sheet. Within layered cardiac constructs, gap junctions are formed which rapidly establish an electrical connection between the cell sheets, leading to $3 \mathrm{D}$ cardiac tissues that synchronously pulsatile [7]. Additionally, when these tissues were transplanted onto the subcutaneous tissue of nude rats, the grafts were macroscopically observed to beat synchronously [8]. Importantly, these implanted tissues also showed long-term survival up to 1 year and 8 months, and the grafts also contained elongated sarcomeres, gap junctions, and well-organized vascular networks within the bioengineered cardiac tissues [9]. 


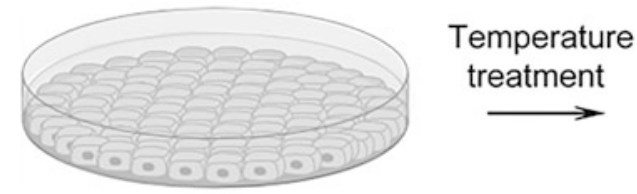

Protease treatment

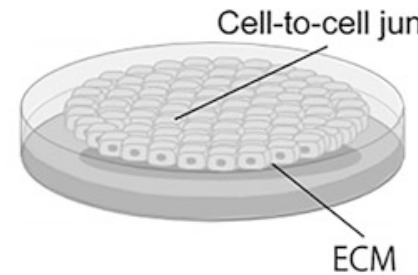

Cell-to-cell junction Temperature reatment
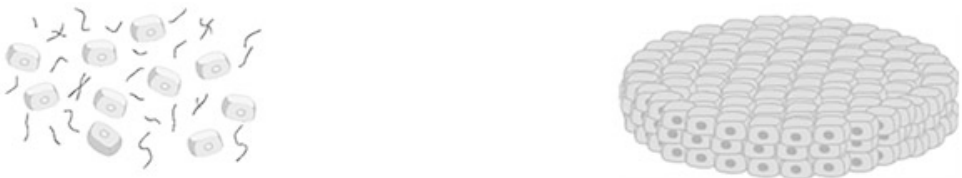

Fig. 3.1 Cell sheet engineering. Using temperature-responsive dishes, cultured cells can be harvested as intact contiguous sheets by simple temperature reduction without proteolytic treatment

\subsection{Cell Sheet Transplantation in Small Animal Models}

Transplantation of engineered tissue such as cardiac grafts onto infarcted rat hearts (Fig. 3.2) demonstrated morphological and functional connections via bridging cardiomyocytes that migrated from the transplanted grafts to the host heart [10]. Cardiac graft transplantation also improved damaged heart function with significant improvements in the host ejection fraction [11]. We have also demonstrated that control of EC densities in engineered cardiac tissues induces enhanced neovascularization and leads directly to improved function of the ischemic myocardium [12]. Moreover, when compared to direct cell injection, the cardiac graft transplantation exhibited superior cell survival and engraftment [13]. Similarly, skeletal myoblast grafts were able to improve left ventricular contraction, reduce fibrosis, and prevent remodeling via the recruitment of hematopoietic stem cells through the release of various growth factors [14]. The implantation of myoblast grafts also induced the restoration of left ventricular dilatation and prolonged life expectancy in dilated cardiomyopathic hamster [15]. Additionally, mesenchymal stem cell grafts demonstrated improved cardiac function in impaired rat hearts, with the reversal of cardiac wall thinning and prolonged survival after myocardial infarction. This recovery after myocardial infarction suggests that the improvement in cardiac function may be primarily due to the effects of growth factor-mediated paracrine and/or a decrease in left ventricle wall stress, which in turn result from the relatively thick mesenchymal stem cell sheets [16]. 

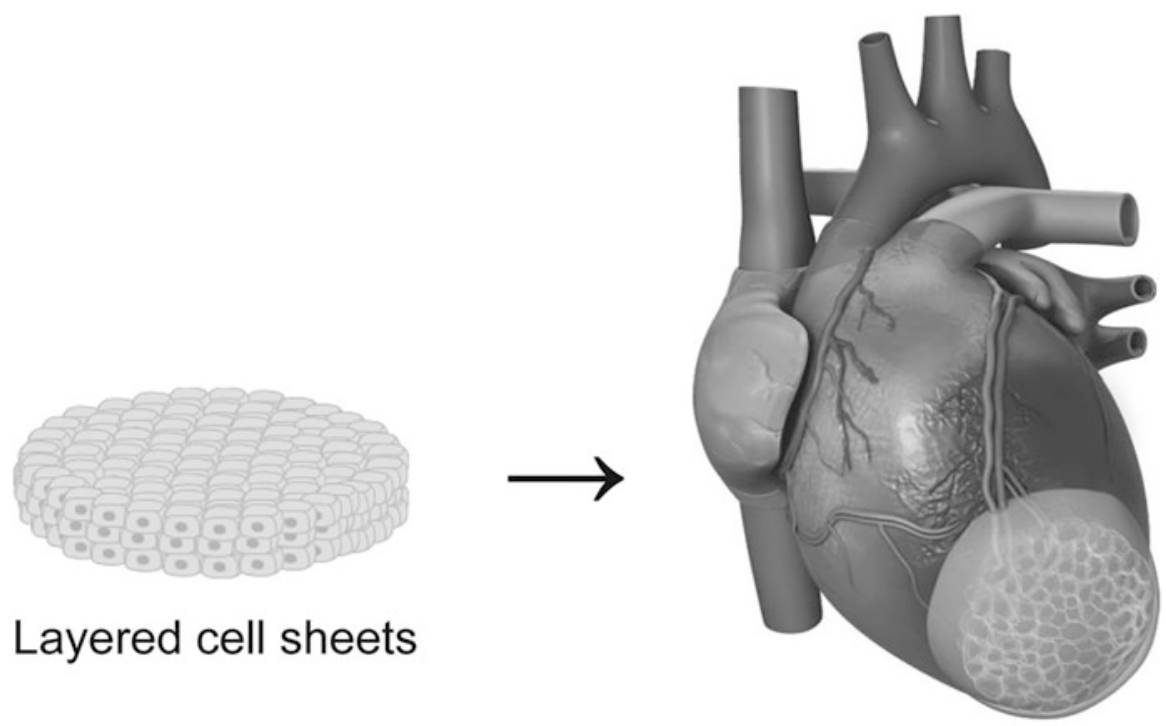

Fig. 3.2 Transplantation of the cardiac grafts onto infarcted rat hearts

\subsection{Cell Sheet Transplantation in Preclinical and Clinical Studies}

Our latest work has been to transplant engineered tissue in clinically relevant largeanimal models. In a pacing-induced canine dilated cardiomyopathy model, transplantation of skeletal myoblast grafts has shown improved cardiac function with reduction of fibrosis and apoptosis [17]. In a porcine cardiac infarction model, skeletal myoblast graft transplantation provided improvement of cardiac function with attenuation of cardiac remodeling [18]. Transplantation of skeletal myoblast grafts has also demonstrated that it is an appropriate and safe treatment for chronic myocardial infarction without increasing the risk of ventricular arrhythmias. Most recently, the transplantation of cardiac progenitor cell grafts derived from embryonic stem cells improved cardiac function without teratoma formation and induced cardiomyogenic differentiation in a simian impaired heart model. Our latest work provides evidence of the safety and efficacy of using embryonic stem cells for myocardial regeneration [19].

Based on the promising results in various animal models, there is a clinical study using cell sheet transplantation currently underway. Autologous skeletal myoblast sheet therapy has demonstrated that it is possible to improve cardiac function to such a degree that LVADs are no longer required for patients with dilated cardiomyopathy [20]. 


\subsection{Conclusions}

The field of tissue engineering presents an exciting approach to regenerative therapies. The future solutions scaling up give more powerful construct creation, resulting in the developments of remarkable tissue-engineered cardiac assist devices or organ replacement. Overall, cell sheet tissue engineering is a novel approach for cardiac treatment that promises efficient and effective alternative therapies in regenerative medicine.

Open Access This chapter is distributed under the terms of the Creative Commons AttributionNoncommercial 2.5 License (http://creativecommons.org/licenses/by-nc/2.5/) which permits any noncommercial use, distribution, and reproduction in any medium, provided the original author(s) and source are credited.

The images or other third party material in this chapter are included in the work's Creative Commons license, unless indicated otherwise in the credit line; if such material is not included in the work's Creative Commons license and the respective action is not permitted by statutory regulation, users will need to obtain permission from the license holder to duplicate, adapt or reproduce the material.

\section{References}

1. Menasche P, Hagege AA, Scorsin M, Pouzet B, Desnos M, Duboc D, Schwartz K, Vilquin JT, Marolleau JP. Myoblast transplantation for heart failure. Lancet. 2001;357:279-80.

2. Orlic D, Kajstura J, Chimenti S, Jakoniuk I, Anderson SM, Li B, Pickel J, McKay R, NadalGinard B, Bodine DM, Leri A, Anversa P. Bone marrow cells regenerate infarcted myocardium. Nature. 2001;410:701-5.

3. Wollert KC. Cell therapy for acute myocardial infarction. Curr Opin Pharmacol. 2008;8:202-10.

4. Laflamme MA, Murry CE. Regenerating the heart. Nat Biotechnol. 2005;23:845-56.

5. Yamada N, Okano T, Sakai H, Karikusa F, Sawasaki Y, Sakurai Y. Thermo-responsive polymeric surfaces; control of attachment and detachment of cultured cells. Die Makromolekulare Chemie, Rapid Commun. 1990;11:571-6.

6. Shimizu T, Yamato M, Kikuchi A, Okano T. Cell sheet engineering for myocardial tissue reconstruction. Biomaterials. 2003;24:2309-16.

7. Haraguchi Y, Shimizu T, Yamato M, Kikuchi A, Okano T. Electrical coupling of cardiomyocyte sheets occurs rapidly via functional gap junction formation. Biomaterials. 2006;27:4765-74.

8. Shimizu T, Yamato M, Isoi Y, Akutsu T, Setomaru T, Abe K, Kikuchi A, Umezu M, Okano T. Fabrication of pulsatile cardiac tissue grafts using a novel 3-dimensional cell sheet manipulation technique and temperature-responsive cell culture surfaces. Circ Res. 2002;90:e40.

9. Shimizu T, Sekine H, Isoi Y, Yamato M, Kikuchi A, Okano T. Long-term survival and growth of pulsatile myocardial tissue grafts engineered by the layering of cardiomyocyte sheets. Tissue Eng. 2006;12:499-507.

10. Sekine H, Shimizu T, Kosaka S, Kobayashi E, Okano T. Cardiomyocyte bridging between hearts and bioengineered myocardial tissues with mesenchymal transition of mesothelial cells. J Heart Lung Transplant. 2006;25:324-32.

11. Miyagawa S, Sawa Y, Sakakida S, Taketani S, Kondoh H, Memon IA, Imanishi Y, Shimizu T, Okano T, Matsuda H. Tissue cardiomyoplasty using bioengineered contractile cardiomyocyte sheets to repair damaged myocardium: their integration with recipient myocardium. Transplantation. 2005;80:1586-95. 
12. Sekine H, Shimizu T, Hobo K, Sekiya S, Yang J, Yamato M, Kurosawa H, Kobayashi E, Okano T. Endothelial cell coculture within tissue-engineered cardiomyocyte sheets enhances neovascularization and improves cardiac function of ischemic hearts. Circulation. 2008;118: S145-52.

13. Sekine H, Shimizu T, Dobashi I, Matsuura K, Hagiwara N, Takahashi M, Kobayashi E, Yamato M, Okano T. Cardiac cell sheet transplantation improves damaged heart function via superior cell survival in comparison with dissociated cell injection. Tissue Eng Part A. 2011;17:2973-80.

14. Memon IA, Sawa Y, Fukushima N, Matsumiya G, Miyagawa S, Taketani S, Sakakida SK, Kondoh H, Aleshin AN, Shimizu T, Okano T, Matsuda H. Repair of impaired myocardium by means of implantation of engineered autologous myoblast sheets. J Thorac Cardiovasc Surg. 2005;130:1333-41.

15. Kondoh H, Sawa Y, Miyagawa S, Sakakida-Kitagawa S, Memon IA, Kawaguchi N, Matsuura N, Shimizu T, Okano T, Matsuda H. Longer preservation of cardiac performance by sheet-shaped myoblast implantation in dilated cardiomyopathic hamsters. Cardiovasc Res. 2006;69:466-75.

16. Miyahara Y, Nagaya N, Kataoka M, Yanagawa B, Tanaka K, Hao H, Ishino K, Ishida H, Shimizu T, Kangawa K, Sano S, Okano T, Kitamura S, Mori H. Monolayered mesenchymal stem cells repair scarred myocardium after myocardial infarction. Nat Med. 2006;12:459-65.

17. Hata H, Matsumiya G, Miyagawa S, Kondoh H, Kawaguchi N, Matsuura N, Shimizu T, Okano T, Matsuda H, Sawa Y. Grafted skeletal myoblast sheets attenuate myocardial remodeling in pacing-induced canine heart failure model. J Thorac Cardiovasc Surg. 2006;132:918-24.

18. Miyagawa S, Saito A, Sakaguchi T, Yoshikawa Y, Yamauchi T, Imanishi Y, Kawaguchi N, Teramoto N, Matsuura N, Iida H, Shimizu T, Okano T, Sawa Y. Impaired myocardium regeneration with skeletal cell sheets - a preclinical trial for tissue-engineered regeneration therapy. Transplantation. 2010;90:364-72.

19. Bel A, Planat-Bernard V, Saito A, Bonnevie L, Bellamy V, Sabbah L, Bellabas L, Brinon B, Vanneaux V, Pradeau P, Peyrard S, Larghero J, Pouly J, Binder P, Garcia S, Shimizu T, Sawa Y, Okano T, Bruneval P, Desnos M, Hagege AA, Casteilla L, Puceat M, Menasche P. Composite cell sheets: a further step toward safe and effective myocardial regeneration by cardiac progenitors derived from embryonic stem cells. Circulation. 2010;122:S118-23.

20. Sawa Y, Miyagawa S, Sakaguchi T, Fujita T, Matsuyama A, Saito A, Shimizu T, Okano T. Tissue engineered myoblast sheets improved cardiac function sufficiently to discontinue lvas in a patient with dcm: report of a case. Surg Today. 2012;42:181-4. 